\title{
Chapter 5 \\ Western Balkans: Deep Integration with EU Relies on Internal Integration
}

\author{
Emmanuelle Boulineau, Antoine Laporte, Clément Corbineau, \\ Charlotte Aubrun, Byron Kotzamanis, Goran Penev, \\ Snjezana Mrdjen, Michail Agorastakis and Ivan Marinkovic
}

\begin{abstract}
This chapter focuses on four stakes: (i) the huge demographic changes of the Western Balkans, and the mobility issue namely due to a re-bordering process since the end of the Yugoslavian wars ; (ii) the undeniable income rise but also rising social disparities; (iii) an economy which is just recovering with strong geographical fragmentation; (iv) in the field of environment, an early stage regulation and the necessity for a rising international cooperation with the European union. We highlight a still low international openness, an obvious core-periphery
\end{abstract}

E. Boulineau $(\bowtie) \cdot$ C. Aubrun

UMR EVS, Ecole Normale Supérieure de Lyon, Lyon, France

e-mail: emmanuelle.boulineau@ens-lyon.fr

C. Aubrun

e-mail: charlotte.aubrun@ens-lyon.fr

B. Kotzamanis $\cdot$ M. Agorastakis

Demobalk, Department of Planning, University of Thessaly, Volos, Greece

e-mail: bkotz@prd.uth.gr

M. Agorastakis

e-mail: magorast@prd.uth.gr

A. Laporte $\cdot$ C. Corbineau

UMR EVS, University Lumière-Lyon 2, Lyon, France

e-mail: antoine.laporte@ens-lyon.fr

C. Corbineau

e-mail: clement.corbineau@univ-lyon2.fr

G. Penev · I. Marinkovic

Demobalk, Institute of Social Sciences, Belgrade, Serbia

e-mail: penev@ sezampro.rs

I. Marinkovic

e-mail: imarinkovic@orion.rs

S. Mrdjen

Demobalk, Department of Geography, University of Zadar, Zadar, Croatia

e-mail: smrdjen@gmail.com

(C) The Author(s) 2016

P. Beckouche et al. (eds.), Atlas of Challenges and Opportunities in European

Neighbourhoods, DOI 10.1007/978-3-319-28521-4_5 
pattern in economic flows with the EU, and the various shortcomings of territorial cooperation with the EU. The strategic recommendations insist on the internal fragmentation, which hinders connection to the EU and any perspective of the Western Balkans to become one day "South-East Europe".

With 21 million inhabitants, the seven countries (including Croatia since ITAN started before its EU membership) form a small neighbourhood (Map 5.1). Compared to the EU, this neighbourhood represents $4.3 \%$ of its population and $5.4 \%$ of its territory $-264,000 \mathrm{~km}^{2}$, just slightly larger than the United Kingdom. The seven states are small, ranging from $11,000 \mathrm{~km}^{2}$ (Kosovo) to $77,500 \mathrm{~km}^{2}$ (Serbia) and from 620,000 (Montenegro) to 7.2 million inhabitants (Serbia).

The fall of the Iron curtain and wars in the former Yugoslavia opened a decade of political, economic, and social turmoil. The 2000 decade was one of progressive

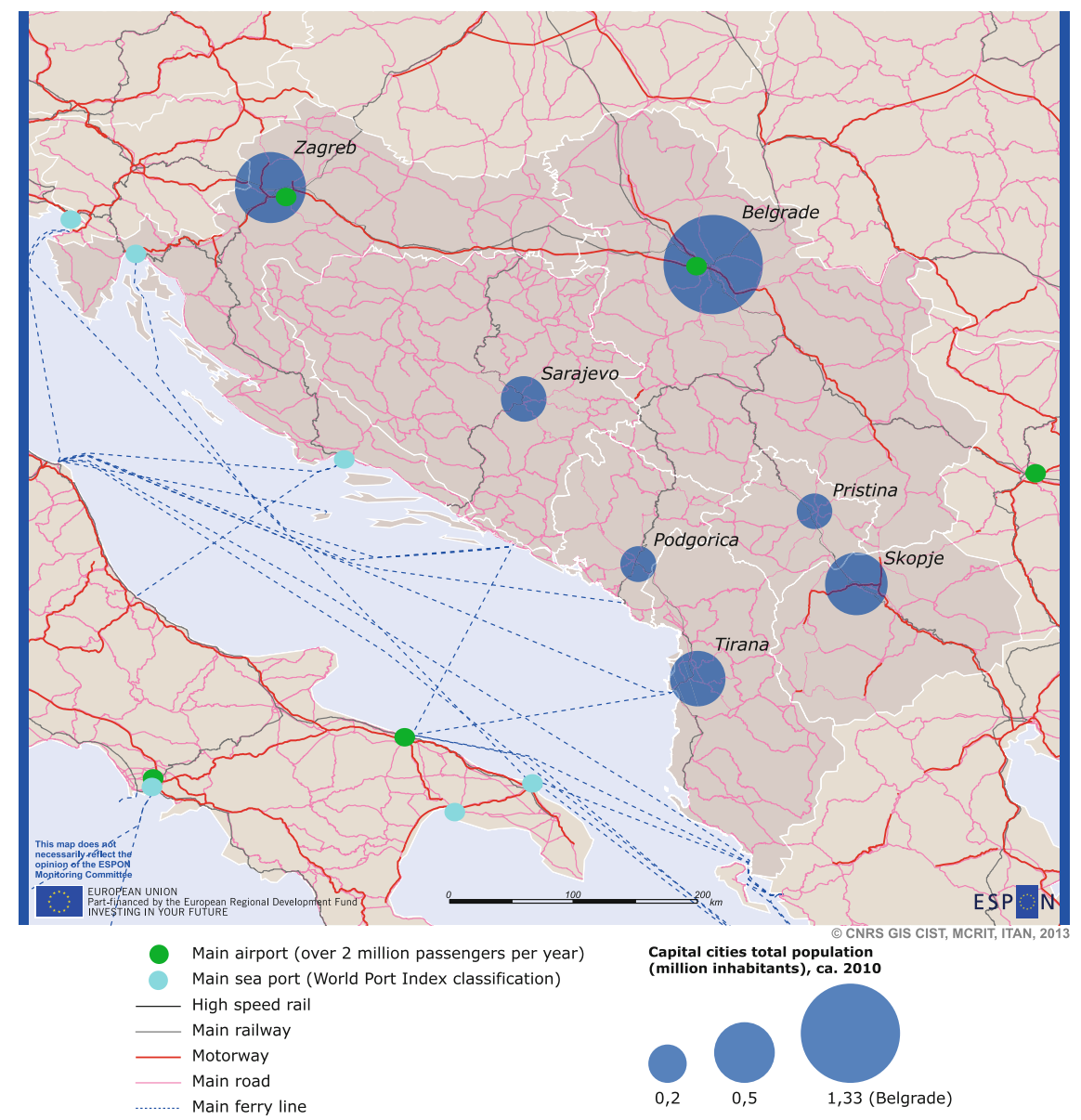

Map 5.1 The South-eastern neighbourhood (Western Balkans) 
internal stabilisation, openness to a globalised economy, and application for EU membership. To different degrees, the seven Western Balkans countries have been in the process of EU integration since the Thessaloniki summit held in 2003, where the EU perspective for the Balkans was confirmed; the Stabilisation and Association Agreements (SAA) were the first steps to membership. Moreover, this neighbourhood is entirely surrounded by EU members: Italy, Slovenia, Hungary, Romania, Bulgaria and Greece.

The post-war context has revealed that fragmentation into states (two states in 1989, seven in 2012) and discontinuities along new borders are a main feature of the Western Balkans. Wars have provoked mobility at all scales, changes in the ethnic composition of populations and economic collapse. Discontinuity, fragmentation and diversity are enshrined in the common word "balkanisation". The fragmentation of space is partly due to the mountains: Balkan is a Turkish word meaning mountain. Another character of the Balkan Peninsula refers to its position as a crossroads of many cultural influences that have contributed to the diversity in European identity.

For young countries, Nation-state building is still an important issue. Different political cultures had emerged during the socialist period. Hence, the actual reform of the territorial and administrative systems raises different national issues and reflects in diverging paths. The delineation of local and regional units to erase the socialist legacy is under question. In the field of competencies, the shift from administrative units, conceived as organs of the central state (state de-concentration), to self-government units (decentralisation) is still an on-going process, challenged by corruption.

\section{$5.1 \quad$ Stakes}

\subsubsection{Huge Demographic Changes, Re-bordering Process and Mobility Issue}

At the end of the 20th century, outmigration was uncontrolled due to profound crises or forced because of wars. Mortality and birth rate were affected by political unrest and economic uncertainty. The demographical change in the Western Balkans is all the harder to cover by statistical means, as methodological problems are manifold for enumerating populations and comparing time series data. Minorities are underestimated due to calls for boycott at the moment of the census; migrations are underestimated due to non-comparable definitions of the resident population according to the different censuses. Where they exist, migrations data from the last censuses (2011) are not yet published in the majority of the countries. Vital statistics (births, deaths) are inaccurate.

Nevertheless, the ITAN project has gathered evidence for an overview. Between 1991 and 2011 the area lost 2 or 3 million inhabitants, a figure that reflects very imperfectly the deep changes that occurred in the Western Balkans during and after the Yugoslavian wars. The achievement of demographic transition and the acceleration of natural decline occurred in the 1990s or the 2000s; in all cases they show 
a convergence with the demographical trends observed elsewhere in Europe. For some countries, namely Croatia, Serbia and the Former Yugoslav Republic of Macedonia, the fertility rate is under 1.5; in Albania the fertility rate dropped from 7 children per woman in the 1960s down to 1.4 in 2008.

Compared to Western Europe, demographic patterns are more deeply influenced by migrations: international migrations have increased because of wars and crises; migrations between the countries of the Western Balkans have developed due to forced migrations (displaced persons), political reasons (refugees) or economic reasons. The ethnic cleansing operations implemented by all belligerent groups had major consequences on the distribution of ethnic groups. In 1996 the United Nation high commissioner for refugees evaluated that Serbia was hosting 540,000 refugees from the conflicts. The war in Kosovo (1998-1999) generated large flows of refugees to Serbia, mostly Serbs and Roma, to Albania and the Fyrom, mostly Albanians. At the peak of the crisis, 300,000 "ethnic" Albanian refugees were seeking assistance in the Fyrom; most of them went back after the war. Lastly, internal migrations in each country have changed the distribution of the population, with concentration in coastal plains and cities as opposed to remote mountainous zones or deprived border areas.

In Croatia, according to the 1991 and 2001 censuses, the population has diminished by $8 \%$. Forced migrations and refugees due to the war (1991-1995) were still larger than the negative natural growth. In the beginning of the $1990 \mathrm{~s}$ there was interplay of emigration from the areas inhabited by the Serb community (Krajina) and immigration from other former Yugoslav republics. In Serbia, according to 1991 and 2002 censuses, the population decreased by 325,000 inhabitants, especially in the eastern part. But the 2002 definition of total population did not take into account the internally displaced persons (IDPs): if they were included in the numbers, the population of Serbia would have increased thanks to net immigration (refugees and IDPs), while natural growth was negative.

The second intercensal period, 2001-2011, covers a decade of political stabilisation-but not demographic stabilisation. In Serbia, some of the long-term processes were speeded up, such as negative natural growth and emigration abroad, while others were slowed down, namely the return of refugees. They led to a population real loss of about 485,000 inhabitants, according to the ITAN expert's estimation. In Croatia, the natural decrease continued while the migration process shifted to outmigration at the end of the period. In Macedonia (Fyrom), the population still increased by natural growth but is now ageing: emigration concerns young people, the elders stay in the villages. For Kosovo, only data for the 1991 and 2011 censuses are available since the 2001 census was cancelled; but both censuses were boycotted, the former by the ethnic Albanians and the latter by the ethnic Serbs. Despite the country having the highest natural increase rate in Europe, estimates provided by the ITAN experts conclude a population decrease, due to forced migrations during the 1990s then economic migrations during the 2000s. Lastly, Bosnia and Herzegovina had a positive population growth over the entire post-war period but Bosnians have been the population by far the most affected by forced displacement. 
When it comes to Albania, strict controls on personal movements had kept high density in rural and mountainous areas under the socialist regime. These measures were lifted in the 1990s and prompted to a demographic shift to urban areas. The censuses show a population loss of about 380,000 inhabitants, that is $-12 \%$ between 1989 and 2011, with a rural population decrease of $-36 \%$. Tirana's growth is not the simple explanation: outmigration was the major process after 1989, and the number of citizens outside the country was estimated at 1 million as early as 2001, especially in Greece - with the current anti-immigrant chauvinism in Greece today. Meanwhile, natural growth has remained positive.

Despite urbanisation, the majority of the population in Albania still live in rural areas, but this statement hides problems of comparison and data availability. Defining the urban population is a major difficulty in all of these former socialist countries. The current definition of the urban population depends on the proper definition of "city" inherited from the socialist period and sometimes modified by laws on territorial and administrative organisation. Moreover, data on urban/rural population are not always provided by national statistical offices at subnational levels, and when they do exist, metadata of the definition are lacking. What is sure is that the overall demographical decline has particularly affected rural areas. Nevertheless, no city, except Belgrade, is inhabited by more than 1 million people (Map 5.2).

Since 1989, the re-bordering process has raised new travelling and visa issues. Previous administrative boundaries between Yugoslav republics have turned into international borders. When villages are shared between two countries, points are locked with gates and the key is given to inhabitants of the village. Secondly, external borders with neighbouring countries have changed their status concerning visa regimes, following the Enlargement of the EU in 2004 and 2007 and the extension of the Schengen area since Hungary (2003), Bulgaria (2007), Romania (2007) and Croatia (2011) signed the Schengen agreement. The Western Balkans countries have improved their capacity in border control, but on the other hand this has deepened territorial fragmentation.

Different factors are pushing young people to project themselves towards Western Europe, in particular the high unemployment rate (e.g. $31 \%$ in 2012 in the Fyrom) and the dismantling of social protection institutions of the socialist states, which places the young population in highly vulnerable situations. Diasporas have a strong impact on social, economic and political life in each national context; remittances are crucial in the daily life for a large part of the populations.

Opportunity to cross borders is generally regarded as one of the top priorities by the population of the Western Balkans. Citizens of Croatia have never been required a visa for stays under three months in the EU. For the other countries, the so-called "liberalisation" of the visa-regime took place progressively: in 2009 for the Fyrom, Serbia and Montenegro; in 2010 for Albania, Bosnia and Herzegovina; Kosovo received a road-map for visa liberalisation in 2012. But this liberalisation generated fearful discourse within the EU on the potential flows of migrants that would spread from there. Yet, small numbers finally managed to leave their country because of the legal obstacles framing their employability and because of the 


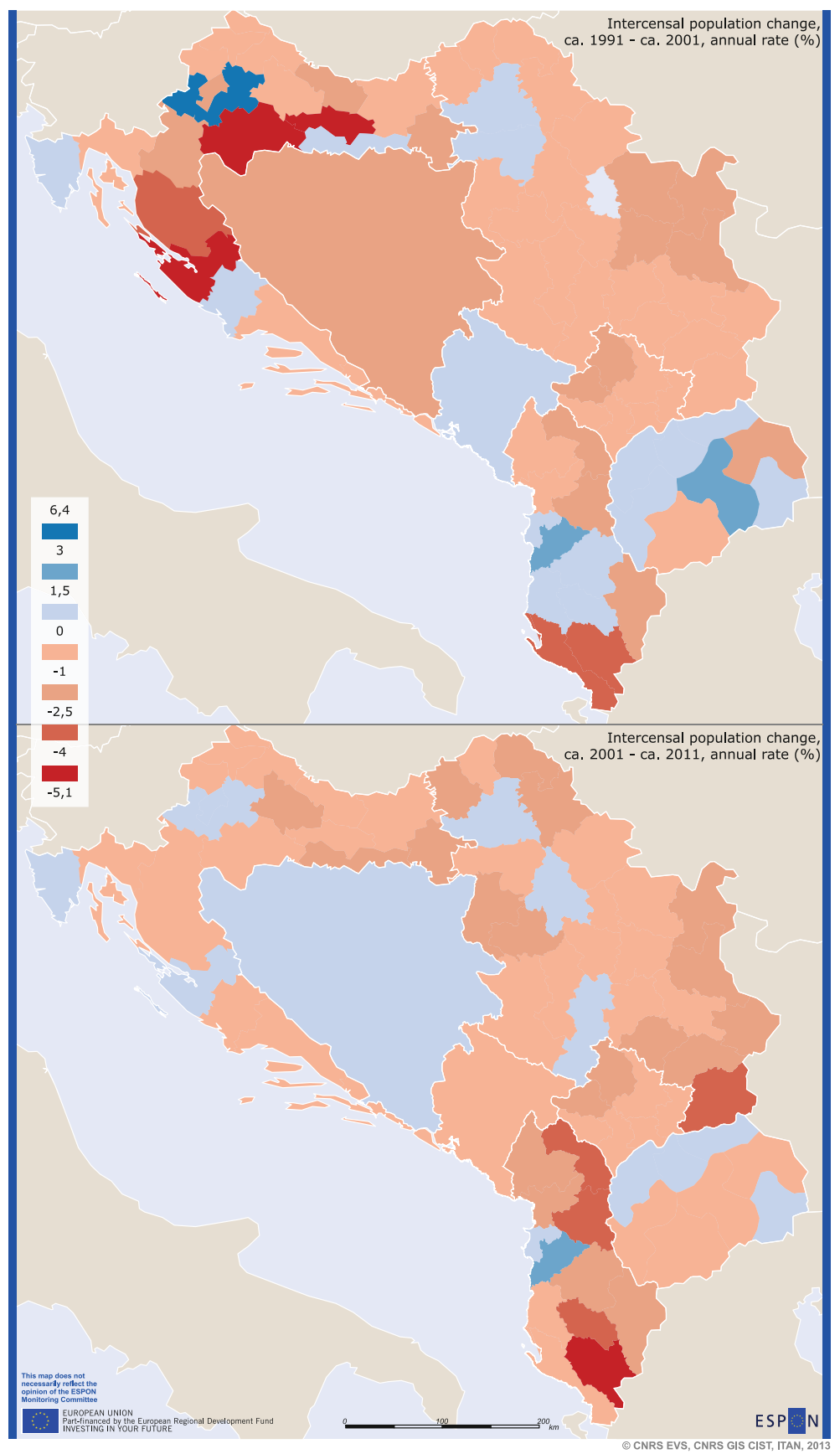

Map 5.2 Population change in the Western Balkans, 1991-2011 
resources needed to migrate. Nevertheless, considering the issues faced by those countries to prevent their nationals seeking asylum in the EU, and taking into account the social conditions of citizens under the readmission agreement, the EU Parliament adopted a visa waiver suspension mechanism in September 2013-a threat for the countries of the Balkans who could see their situation downgraded. In 2013, the Western Balkans became one of the hotspot targeted by Frontex as one of the seven high-risk irregular migration routes. This penalises Western Balkans citizens: they accounted for $85 \%$ of the total irregular border crossing in 2010, but for only $27 \%$ in 2012. Due to the reduction of the demographic reservoir by the population decline, a push factor of migrants from the Western Balkans countries towards Europe should not be expected. Furthermore, migrations are changing to temporary stays in western countries: mobility is replacing migration.

Progressive integration to the EU also creates uncertain situations within the Western Balkans. To avoid critical transition situations, countries are experiencing a flexible regime. This is the case at the border between Croatia and Bosnia and Herzegovina since 2013 when Croatia entered the EU. The border crossing issue was a major discussion topic during the tri-lateral meetings held between $\mathrm{BiH}$, Croatia and the EU. Whereas until then Bosnian citizens could cross the Croatian border with only an ID card, the integration of Croatia into the EU forced them to get a biometrical passport. That is why the parties agreed on the creation of a 5-km buffer zone along the Croatian border in BiH: any Bosnian citizen justifying his residence there and maintaining economic activities or family ties on the other side of the border is entitled to special easier conditions for crossing the border. This example proves that, as in the other places of the greater region, mobility of people is one of the top stakes of the neighbourhood issue.

\subsubsection{Social: Undeniable Income Rise, Rising Social Disparities}

Twenty years after the fall of the socialist regimes, the improvement of social conditions is indubitable. At the end of the 1980s, the scientific literature was still talking about development; now, according to the World Bank, the Western Balkans countries have entered the ranks of upper middle income countries, even though social disparities are also more contrasted.

In 2000, the infant mortality rate was above $10 \%$ in the Fyrom, Albania, Serbia and Montenegro. Ten years later, infant mortality remains higher than in the EU but the decrease is remarkable, with a reduction of 6 to 4 points. In Serbia, the south-eastern regions, which are also outmigration areas, have higher infant mortality rates (Map 5.3). Contrary, the northern part of Croatia on the Danube plain has a very low infant mortality: the decrease of births and the improvement of social and health conditions reduce mortality of very young children. In Bosnia and Herzegovina it is difficult to understand regional disparities: the reliability of data is at stake. Kosovo keeps the highest rate, above $10 \%$. 


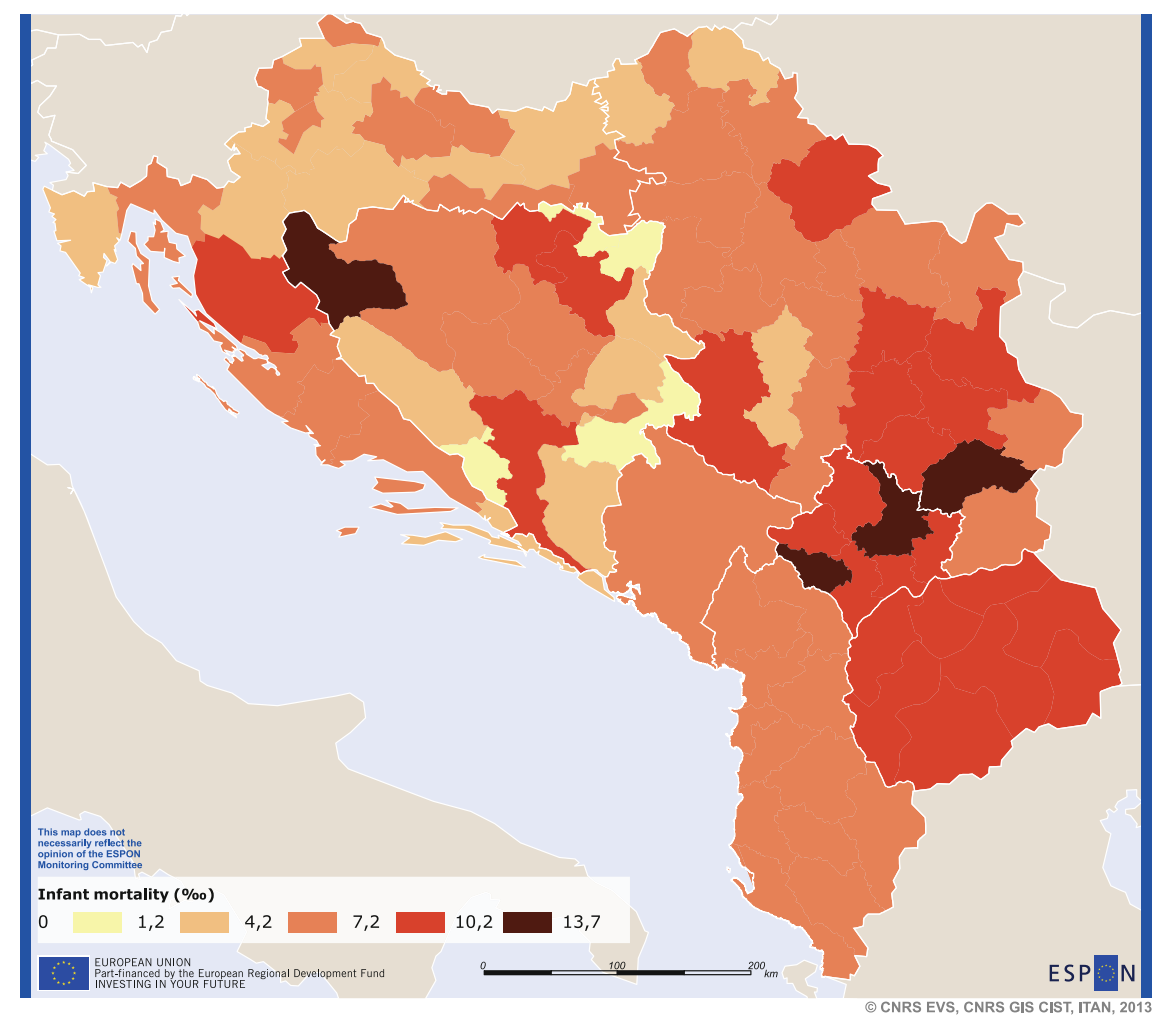

Map 5.3 Infant mortality in the Western Balkans, ca 2010

As for the local human development indicator (see supra Map 2.37), Dalmatian Croatia and Montenegro present a profile close to the neighbourhoods' average. Serbia and the Former Yugoslav Republic of Macedonia are in a more difficult situation: the level of educated population and incomes hinder the human development. All the Western Balkans present a real asset: an improved life expectancy.

Indicators such as unemployment rate show that the transition to a liberal economy has deeply affected the labour market: the shutdown of state-run enterprises and the end of socialist full employment led to increasing unemployment and to the impoverishment of the population. The 2008 crisis in Western Europe has also hit economies with a different acuity. But statistical offices and Eurostat draw attention on the lack of reliability regarding unemployment statistics due to the share of informal economy. In 2011, official unemployment rates were above $20 \%$, ranging from $20 \%$ in Kosovo to $31 \%$ in the Fyrom.

In Albania, the World Bank says that poverty is reducing both at national and regional level; however, regional disparities persist. From 2005 to 2008, central areas had the largest reduction in poverty, from $21 \%$ of the total population to $11 \%$; in mountainous areas, one out of four individuals was still recorded as poor with no change between 2005 and 2008 (Table 5.1). 
Table 5.1 Equipment indicators in the Western Balkans

\begin{tabular}{|c|c|c|c|c|}
\hline & \multicolumn{2}{|c|}{$\begin{array}{l}\text { Motor vehicles } \\
\text { (per } 1000 \text { inh.) }\end{array}$} & \multirow{2}{*}{$\begin{array}{r}\begin{array}{r}\text { Internet users } \\
\text { (per } 100 \text { inh.) }\end{array} \\
2010\end{array}$} & \multirow{2}{*}{$\begin{array}{l}\begin{array}{l}\text { Mobile cellular } \\
\text { subscriptions } \\
\text { (per } 100 \mathrm{inh} . \text { ) }\end{array} \\
2010\end{array}$} \\
\hline & 2004 & 2010 & & \\
\hline Albania & 87 & 124 & 45 & 84 \\
\hline Bosnia and Herzegovina & 113 & 214 & 52 & 83 \\
\hline Croatia & 337 & 380 & 57 & 112 \\
\hline Macedonia (Fyrom) & 136 & 155 & 52 & 105 \\
\hline Kosovo & n.a. & n.a. & n.a. & n.a. \\
\hline Montenegro & n.a. & 262 & 38 & 185 \\
\hline Serbia & 234 & 238 & 41 & 122 \\
\hline European Union & & 547 & 75 & 130 \\
\hline
\end{tabular}

\subsubsection{Economy: Still Recovering, Still Geographically Fragmented}

The Western Balkan's economy is still recovering from the wars' impact. Data prior to 2000 are not really reliable, when they do exist. After 2000, definitions and metadata better comply with international and European recommendations, such as calculation of gross domestic product and foreign direct investments in national accounts. Time series are reduced and data are often lacking at regional level. The openness of economies to a globalised world has been brutal and reveals economic assets and weaknesses.

Assets are real: important labour force and low dependence ratio; good level of education especially in Croatia, Serbia and Montenegro, with lower rates in southern countries, in particular for women in Kosovo and in Albania (where the illiteracy rate for children above ten years is $3.7 \%$ for females against 1.7 for males); low gender imbalance in the field of training (in Bosnia and Herzegovina, in 2011 women represent more than $60 \%$ of graduated students).

Shortcomings are high, though. Gender imbalance in employment, to begin with: the female employment rate ranges from $34 \%$ (especially in the southern part, that is to say Montenegro, Albania and the Fyrom) to $42 \%$, far from the European average of $59 \%$. The most developed regions such as capital regions of Zagreb and Belgrade, Istria in Croatia and Novi Sad in the Serbian Vojvodina, are the closest to the EU levels. For people with tertiary education, outmigration is an opportunity when they could not find a job, because jobs are lacking; informal employment constitutes another response to this mismatch. Compared to the EU where the average employment rate reaches $64 \%$, the rate is lower in all the Western Balkans countries.

GDP per capita is double in 2010 than in 2000 and approximates the level of Bulgaria (4800 €). However, differences of level are sharp: discrepancy of GDP between the richest areas and the poorest is twelve times. A gradient from the north-western part down to the south-eastern part is striking: Croatia is by far the 
country with the richest regions - Zagreb city district's per capita GDP is $18,700 €$ whereas that of Pološki region in the Fyrom is 1600. Generally speaking, in these traditionally centralised countries, the highest amounts of GDP per capita are in the capital city districts: Zagreb, Belgrade, Skopje and Tirana. GDP growth emphasises the dissociation between the dynamic paths of the capital city districts and the rest of the countries, especially in the southern countries of the Western Balkans. Geographical disparities are clearly on the rise, except in Albania where the GDP per capita in Tirana was four times higher than that of the Dibër district in 2000 and only two times in 2010 - but except the Tirana district, all of Albania is lagging behind, under the Western Balkans' average both in 2000 and in 2010 (Map 5.4).

High added-value services are under-represented except in Croatia and in Serbia. The high share of agriculture relates to the importance of the rural population in most of the countries, in particular in the southern ones.

Geography of trade tells a lot about the internal cohesion of Western Balkans. Since the Soviet-Albanian split (1961), Albanian trade with neighbouring countries was limited. In the 1980s, trade between the Balkan countries was estimated at less than $10 \%$ of their external trade. During the Yugoslavian wars, embargoes, grey

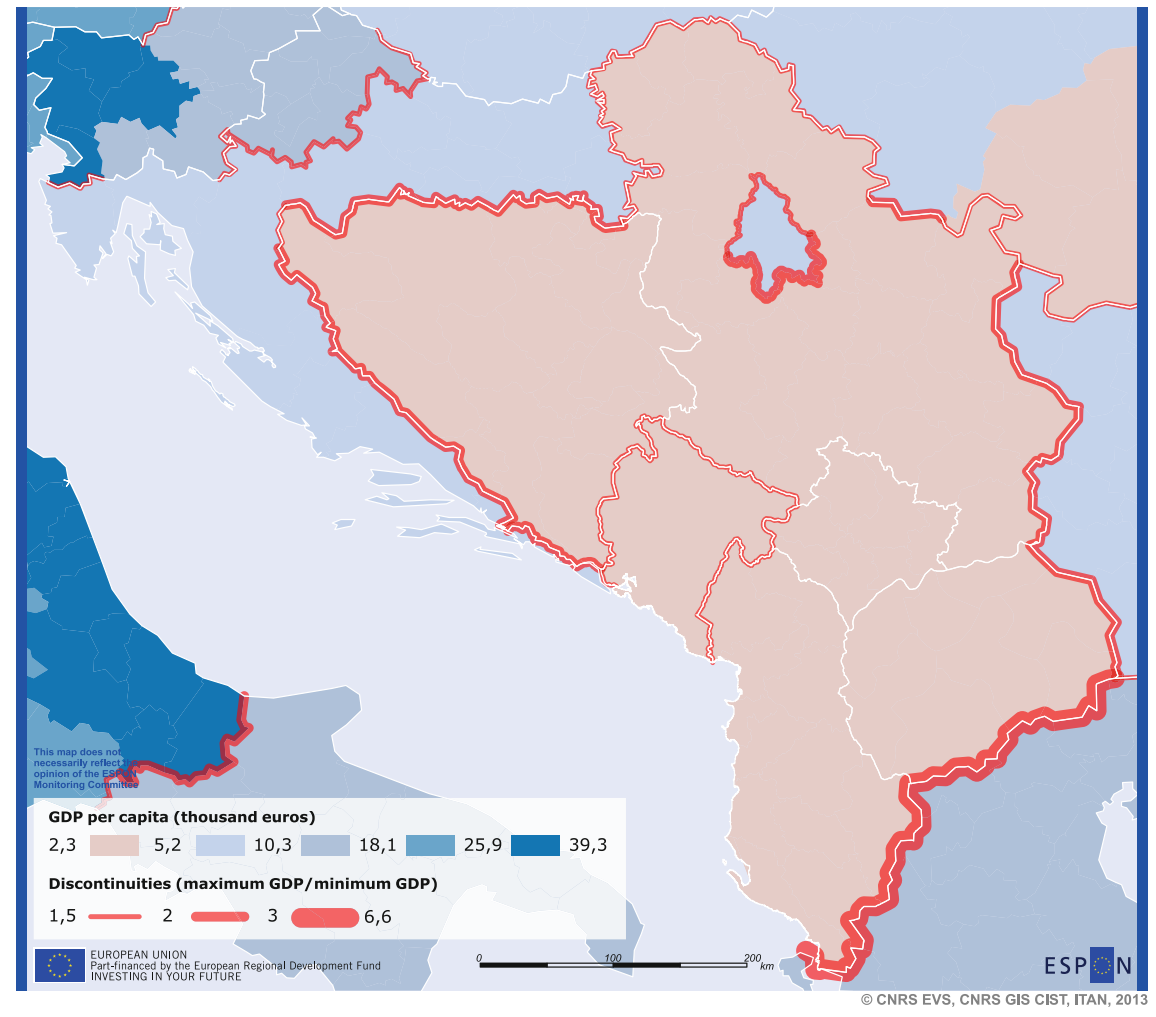

Map 5.4 Discontinuities of regional GDP in the Western Balkans, 2010 
economy, illicit trade and corruption developed. Despite the 2000 decade opening with stabilisation and trade opportunities for the seven states, the area still suffers from a high fragmentation of its national markets. The Central European free trade agreement (CEFTA) fosters trade cooperation, in accordance with WTO procedures and EU regulations. Croatia entered in 2002, the Fyrom in 2006, the agreement came into force in 2007 for Bosnia and Herzegovina, Serbia, Montenegro, Albania and Kosovo. The CEFTA is considered as a preparation for European Union membership: previous members have left when entering the EU, namely the Visegrad group (Czech Republic, Slovakia, Hungary and Poland) and Slovenia in 2004, Bulgaria and Romania in 2007. Membership in CEFTA requires to have contracted an Association and Stabilisation Agreement (ASA) with the EU, and to have ratified bilateral trade agreements in the framework of the Stability Pact for southern Europe. Yet, in 2012, intra-CEFTA trade corresponded to only $16 \%$ of the external trade of the Western Balkans countries, ranging from $10 \%$ for Albania to $48 \%$ for Montenegro (especially with Serbia). The ratio for Croatia was $12 \%$, compared to the $63 \%$ share of the EU in the country's foreign trade - at a time prior to its entry into the EU (Map 5.5).

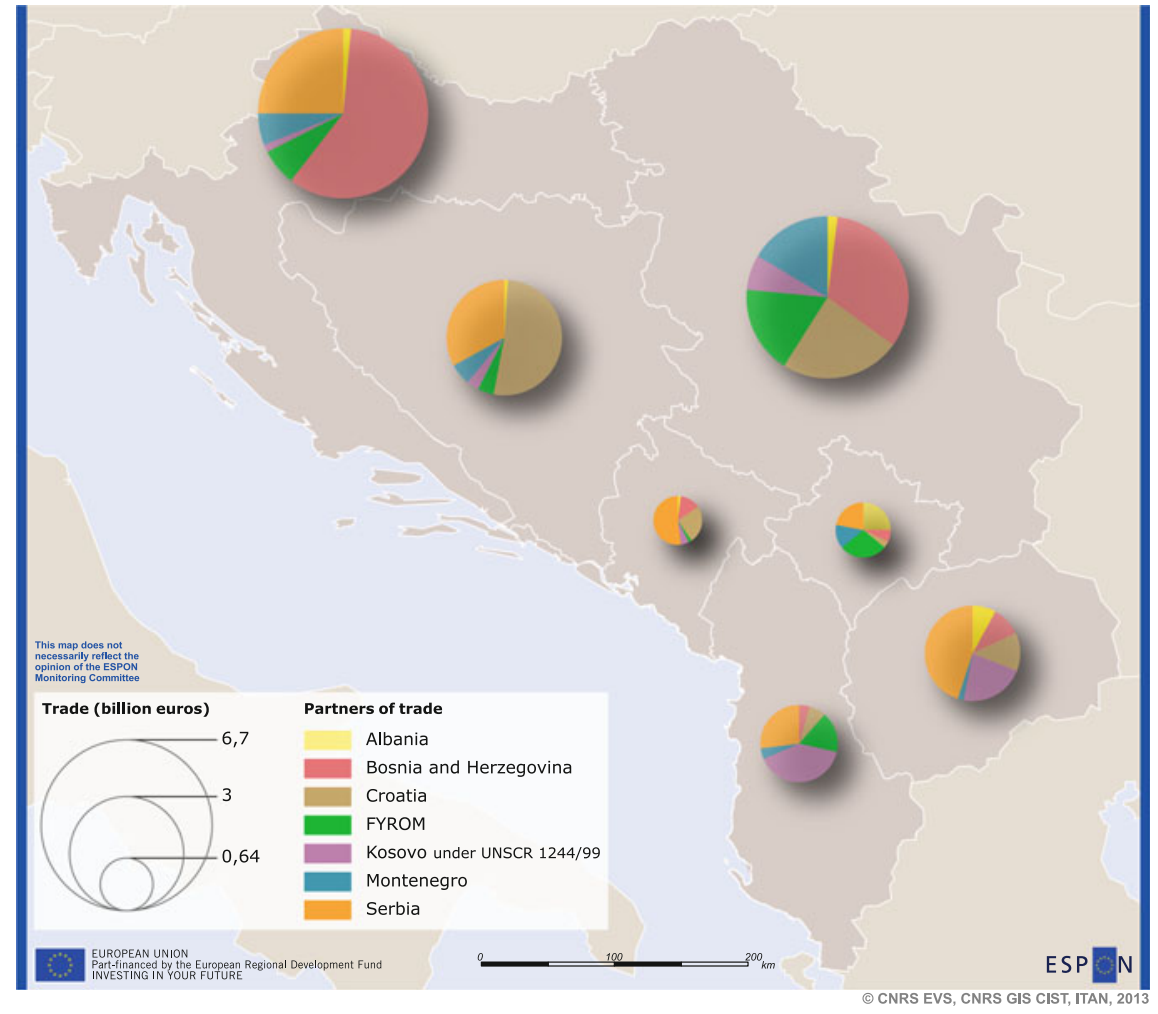

Map 5.5 Trade (\%) between the countries of the Western Balkans, 2012 
Geography of energy flows also tells us a lot about internal cohesion and connection to the EU. The Western Balkans are not an energy provider but are situated at the crossroads of energy roads from the Russian and Caspian fields to the EU. The 1990s crisis emphasised the obsolescence of the socialist legacy in energy supply: out-dated networks, high level of losses-still estimated in 2005 at $22.5 \%$ for the entire area. After the collapse of consumption during the 1990 decade, and the perspective of both economic growth and increasing domestic demand, the countries face new needs in energy supply and modernisation.

As late as 2003 domestic coal and lignite were the major source of energy for Serbia and Montenegro (56 \%), Bosnia and Herzegovina (56 \%), the Fyrom (51\%) while Croatia and Albania were more dependent on oil. The diversification of both energy resources and suppliers are yet at stake. Due to the socialist policy of self-reliance, energy networks were not interconnected between countries whereas safe access to Soviet pipelines was not ensured. Today, projects of transnational roads through the Balkans and interconnections of networks are caught between bi-lateral agreements with western European states, and the Russian will to bypass the Turkish straits for exporting oil and gas more directly to the EU.

\subsubsection{Environment: Early Stage Regulation, Necessary and Rising International Cooperation}

According to the 2013 national progress reports of the European Commission for the candidate countries or potential candidate countries, the alignment on the acquis communautaire in the field of the environment is most often qualified as "in little progress" or "at an early stage". National strategies and policies are incomplete: for example, there are no regulatory frameworks in any country of the area concerning climate change, except in Croatia. Regulations are adopted in the field of the Water Framework directive (as in Serbia) or Birds and habitats directives (Serbia, Republika Srpska in Bosnia and Herzegovina, for example) but implementation is delayed due to the lack of administrative capacity - namely inter-sectoral cooperation between ministries, which is indispensable for the environment which is a transversal field. Regulations are lacking to fulfil European recommendations or international ones such as the United Nations Millennium Goals for Environmental Sustainability. Nonetheless, the measures enhancing territorial cooperation in the field of the environment seem to elicit interest in these countries.

The development of protected areas needs to be tied with tourism and with the fight against rural poverty, especially in the mountain areas where density is low and outmigration high. Some countries, like Croatia and Albania, are ready for the establishment of Natura 2000 networks and protected areas. Thus, Albania increased the share of the territory under protected areas from $10 \%$ in 2007 to $15 \%$ in 2012. According to the European Environment Agency, the areas under natural protection cover now $10 \%$ of the Western Balkans (the ratio is $22 \%$ for the EU). 
Generation of municipal waste has risen in the Western Balkans and it is currently at levels similar to those in the new EU member states. While $92 \%$ of the population in Croatia is served by organised municipal waste collection schemes, four-fifths of the waste generated by economic activities is disposed of in landfills or waste discharges. In Bosnia and Herzegovina, only $60 \%$ of the population is served by organised municipal waste collection, when it works correctly. In Serbia, eight regional centres and one plant for dangerous waste are planned. Illegal waste dumping and random waste deposit areas increased during the period of economic crises and wars. Since then, the reduction of such illegal waste deposit is confronted to the lack of cooperation between local and central authorities, in countries where decentralisation processes are problematic.

Water supply systems have become obsolete and insufficient. Albania has only one working wastewater treatment plant. In Montenegro, loss of water increased by $5 \%$ between 2008 and 2011. In Kosovo, less than a third of the population has access to a sewer system. In Bosnia and Herzegovina $90 \%$ of wastewater is reportedly released without treatment; in Serbia $84 \%$ of the population are not served by water treatment plant.

The need for cross-border cooperation is now identified in all these countries as a necessity to fight against flood episodes or drought in the southern part, between Albania and the Fyrom, for example. Macro-regional strategies supported by the EU or Euro-regions supported by the Council of Europe could help to tackle environmental issues. Much of the Western Balkans' water resources are shared between countries. About $60 \%$ of Croatia's territory and over $70 \%$ of Bosnia and Herzegovina's lie in the Danube River basin. In Serbia, over $90 \%$ of water resources flow from neighbouring countries. The Fyrom's main river basins flow through Albania into the Adriatic Sea and through Greece into the Aegean Sea. Frequents episodes of floods have been registered in the several countries of the Balkan Peninsula during the last decade, as well as heat waves and droughts. The launching of international cooperation, such as the Danube River Protection Convention entered into force in 1998 and the Framework Agreement on the Sava River Basin in 2002 have been ratified by the concerned countries. It was a first step to adopting international and European standards to fight against pollution, develop protection of the waters, and to implement path towards the EU Water Framework Directive.

\subsection{Strategic Synthesis: Connection to EU Hindered by Internal Fragmentation}

\subsubsection{Still Low International Openness: Role of Transport Infrastructures}

The Western Balkans new assets could be found in their position at a crossroads on international roads. Nevertheless, they suffer from a low international openness index, quite similar to that of northern Africa, and from low internal integration within Western Balkans. 
In Croatia, as the more stable economy, the three regions are well connected and attract foreign investment (FDI). The Dalmatian seashore is connected to maritime trade by the international ports of Rijeka and Split. The capital region of Zagreb has an international airport, and the north-western region is well connected to the Danube plain which is the main path to Western Europe. The same situation characterises the city of Belgrade, with its international airport and the northern regions of Serbia (Vojvodina and the area around Belgrade): the Morava river valley leads to the Danube northwards and attracts the major part of the FDI in Serbia. For Albania and the Fyrom, the proximity to the port of Thessaloniki and the domestic port of Shköder close to Italy, give these countries a spatial advantage. The other countries are rather landlocked (see Map 3.3).

The railway network has both a low density and a lack of hierarchy; countries are not connected to all their neighbours. The ancient Orient Express line between Paris and Istanbul, running through Belgrade on the way from Budapest to Sofia, is now a touristic attraction. In the northern part, the legacy of rail development under the Austro-Hungarian Empire has given Croatia and Bosnia and Herzegovina a dense network, but it was seriously damaged during the 1990s wars. Maintaining the network - the destruction of the rail network is estimated at $80 \%$ in Bosnia and Herzegovina - still needs subsidies whereas countries focus their efforts on road networks. A project for the modernisation of the Budapest-Belgrade line into a high speed railway was launched at the end of 2013 thanks to ... Chinese investments.

The road network was mainly developed in the second half of the 20th century according to the socialist logics: priority was given to domestic networks rather than international connections. Even today, there is no motorway in Bosnia and Herzegovina, in Montenegro and in Albania. During the 2000s, the motorways length has been increased by 3 in Croatia, by $80 \%$ in the Fyrom and by $60 \%$ in Serbia.

As a consequence, transport networks represent strong discontinuities. Only Zagreb and Belgrade have airports with traffic of over 2 million passengers per year. Main sea ports are concentrated in Croatia (Rijeka and Split). High speed road networks are not yet completed at borders (between Serbia and Bulgaria, Serbia and the Fyrom) or simply non-existent. With the expansion of road traffic and controls at EU borders, congestion at checkpoints arises. The lack of networks' hierarchy concentrates flows on domestic single axes with a risk of congestion on the one hand and, on the other hand, a risk of marginalisation for some internal regions, such as central Bosnia and Herzegovina, North of Montenegro and South-East of Serbia, Kosovo and the western Fyrom.

In the framework of the 2014-2020 programming period, the Trans-European transport network (TEN-T) "Orient-East Med" is expected to join the ports of Athens-Piraeus and Thessaloniki (Greece) and the port of Burgas on the Black Sea (Bulgaria) to Budapest through EU member countries: Sofia, Craiova, Timișoara in Bulgaria and Romania. Thus, the historical central nodes from the Mediterranean Sea to Central Europe such as Skopje and Niš are bypassed. The Western Balkans could stay on a periphery out of main road axes to Europe. For Bosnia and Herzegovina, Kosovo and the Fyrom, as landlocked countries, accessibility could decrease. 


\subsubsection{Economic Flows with the EU: A Core-Periphery Pattern}

The Western Balkans represent a very minor share of relations and flows of the EU: $0.5 \%$ of its trade of goods (2011); $0.2 \%$ of the FDI in and outflows; $0.7 \%$ of air flows; $0.3 \%$ of energy supply, and $6.1 \%$ of migrations. The economic interest of the Western Balkans for the EU is all the more minor as their markets are fragmented. But this fragmentation hampers their recovery, hinders the formal economy, and prevents them from becoming a stable area in the near future. This, by contrast, is of major political importance for the Europe Union.

Foreign Direct Investments are of utmost importance to Western Balkans' economies: there were few savings left by socialist regimes; wars have degraded infrastructures and industries; obsolete technologies need to be updated. At the beginning of the process, openness to FDI relied on a large privatisation of state owned enterprises, as was the case in central and eastern European countries before EU accession. Then, at the end of the 2000s, Western Balkans countries developed investment promotion agencies; they introduced a low corporate income tax and are still benefiting from a cost competitive workforce to attract investments. What is the actual result?

For the period 2008-2012, the average share of FDI inflows in GDP ranks from $3 \%$ in Bosnia and Herzegovina to $8 \%$ in Albania, with Montenegro far ahead (20\%). By comparison, in Bulgaria which entered the EU in 2007, FDI inflows represented $31 \%$ of the GDP, from $6 \%$ in 2000. In Croatia, on the eve of its EU integration, the share of FDI in the GDP was only $2 \%$. The importance of FDI in this neighbourhood's economy can thus be considered low. This does not help the shift towards a technology-improving or knowledge economy, which is only engaged in Croatia.

A positive element for regional integration is that the EU + EFTA countries are the first investors there: they are the origin of the majority of the FDI in the Fyrom (70 \%) or in Serbia (91\%), and $34 \%$ in Bosnia and Herzegovina (Map 5.6). South-Eastern neighbour countries are narrow markets but the EU accession perspective increase confidence as well as the market size. However, EU progress reports stress the need for further improvement of business conditions and legislation to warrant investments; the business environment needs improvement in the fight against corruption and informal procedures, and an effort in the quality of infrastructures and energy supply. Moreover, only in Croatia are FDI mostly oriented towards upper level services. By contrast, foreign investors target cheap labour intensive industries in Albania (average wage around $150 €$ in 2012) and Kosovo $(300 €)$. Tourism and common services are frequent targets of foreign investors in the Western Balkans.

When it comes to trade, the EU and EFTA countries represent $57 \%$ of the CEFTA members' trade, far ahead of the intra-CEFTA trade share (16\%) as noted above. Serbia and Croatia, as the bigger countries in the Western Balkans, have a positive trade balance with other CEFTA members but the trade balance of all the 


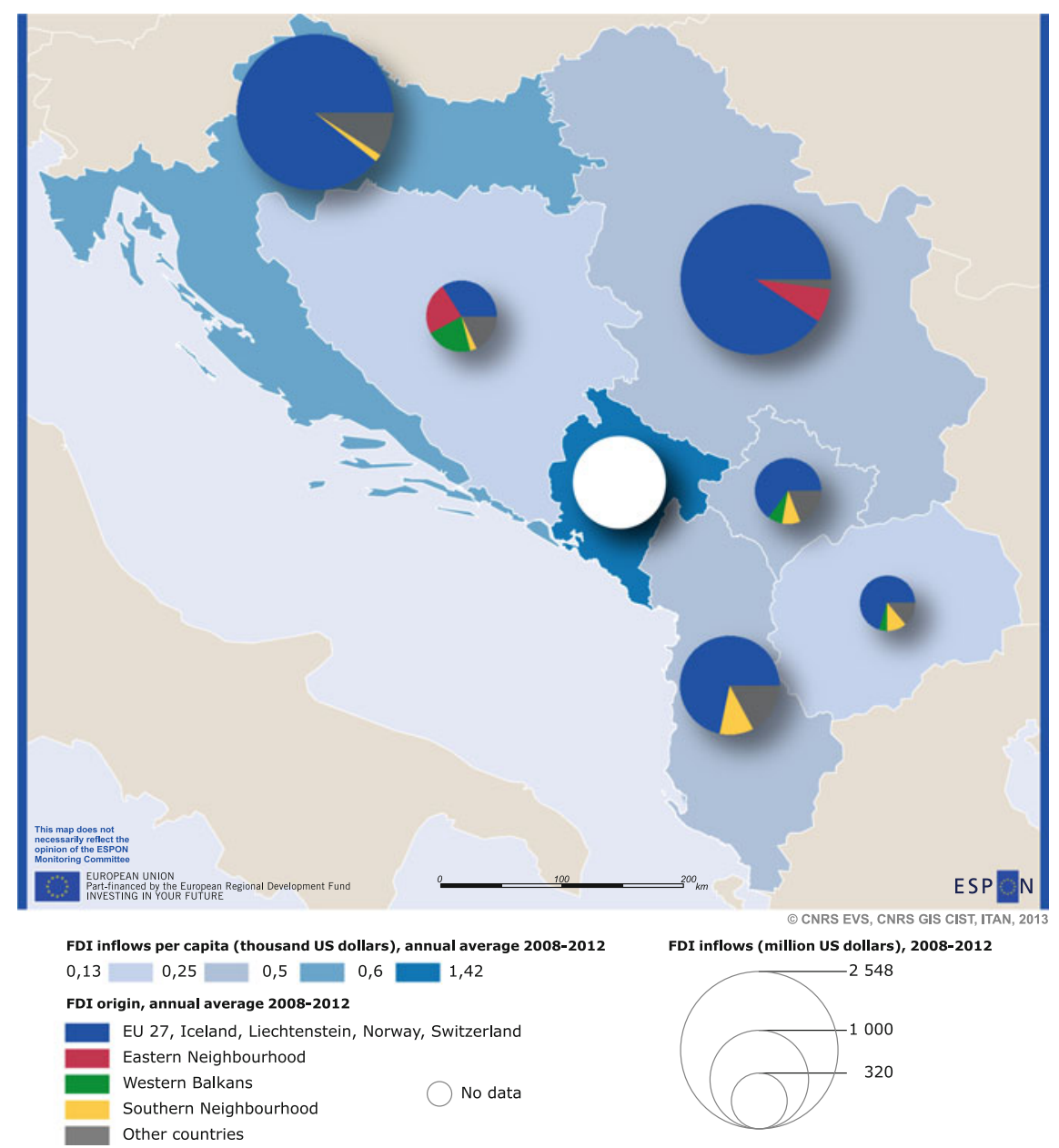

Map 5.6 Origin of FDI by regions, 2008-2012

CEFTA members is negative with non-CEFTA partners, especially with EU and EFTA members.

When it comes to public aid, Official Development Assistance (ODA) towards the Western Balkans is in a large extent ensured by EU institutions, EU member states and EFTA countries. Serbia gets the highest amount of ODA, of which $86 \%$ from European sources. Kosovo is second in rank: international supervision has been replaced by that of the EU, including in the field of development aid, even if the USA appears at the second rank of contributors. The Fyrom and Montenegro have the lowest European dependency rate $(66 \%)$ due to the place of Turkey among donors. In Albania, Islamic organisations or countries, such as the Islamic Development Bank and Kuwait are significant contributors. 
As a whole, the geographical breakdown of trade, FDI and ODA show a strong dependency of this neighbourhood vis-à-vis Europe. Flows are unbalanced (trade balance negative, one way FDI), the core-periphery pattern characterises the regional integration of the Western Balkans in the EU. One of the reasons is related to the Western Balkans themselves: this neighbourhood is not a unique area that would be well connected and economically integrated. Moreover, southern states (Albania, Kosovo and the Fyrom) also attract Turkish investment, Serbia and Bosnia and Herzegovina attract increasing Russian investment.

\subsubsection{Measuring the EU's Diplomatic Influence}

Getting back to the non-resident embassies and corresponding embassies analysis, we can display the diplomatic areas of influence upon the Western Balkans. Indeed, the number of non-resident embassies is inversely related to the diplomatic weight of the country: Belgrade or Zagreb host more resident embassies than non-resident ones. This is the contrary for the other countries. As a whole, according to all the diplomatic representations, the Western Balkans clearly belong to the EU's area of influence. Geographical and political proximity of Western Europe is incomparably higher than in the case of the Black Sea area (see Sect. 4.3.2).

In Italy, 65 embassies are competent for the Western Balkans countries (Map 5.7) -nevertheless it has to be said that Rome counts "double" due to the fact that the Italian capital city is both the head of Italy and Vatican. In particular, Rome hosts 27 non-resident embassies for Albania, that is to say twice as many as Greece which hosts 14 non-resident embassies for Albania. After Rome, Vienna and Budapest are at the second and third rank, with 46 and 41 non-resident embassies. The legacy of the Habsburg Empire is still visible in the lands that were under its rule. At the fourth rank, Belgrade hosts 39 non-resident embassies of which 24 for Montenegro, the last state that declared its independence from the Former Yugoslavia in 2005 (if we exclude Kosovo). Then other Balkans capital cities, Sofia and Athens host around 20 non-resident embassies: the diplomatic influence of Greece upon the Western Balkans appears to be surprisingly low and limited to Albania (Map 5.8).

\subsubsection{Shortcomings of the Territorial Cooperation Between the $E U$ and the Western Balkans}

Two macro-regional strategies are related to Western Balkans countries:

(i) The Danube macro-regional strategy (EUSDR), adopted in 2010, encompasses fourteen countries (totally or partially) and is based on the Danube river catchment basin. Four countries of the Western Balkans are included: Croatia, Bosnia and Herzegovina, Montenegro and Serbia. But as a matter of fact, the 


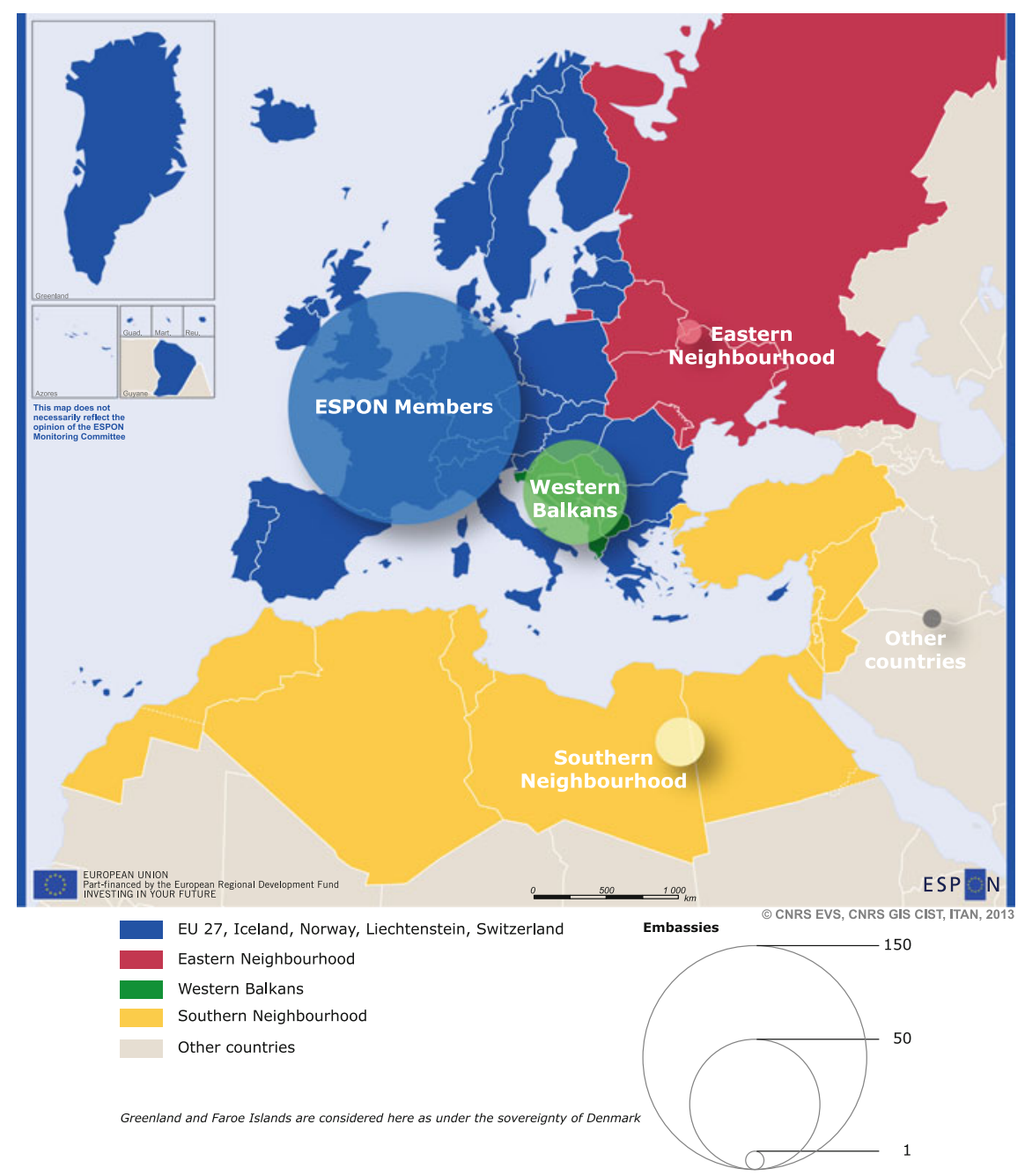

Map 5.7 Number of non-resident embassies competent for the Western Balkans countries

interest of the Western Balkans countries is not obvious: during the consultation phase, among 92 respondents only one Croatian association answered the European Commission's call.

(ii) The Adriatic-Ionian macro-region strategy (EUSAIR) was endorsed in 2012 by the European Council. The macro-region was officially launched in 2014. It encompasses eight countries: Greece, Italy (nine regions), Slovenia as EU member states, Albania, Bosnia and Herzegovina, Croatia, Montenegro and Serbia, and stretches on both sides of the Adriatic Sea. But since this macro-region strategy is built on a territorial discontinuity, that of the Adriatic Sea, and since Western Balkans are fragmented, this strategy might have low impact on this neighbourhood. 


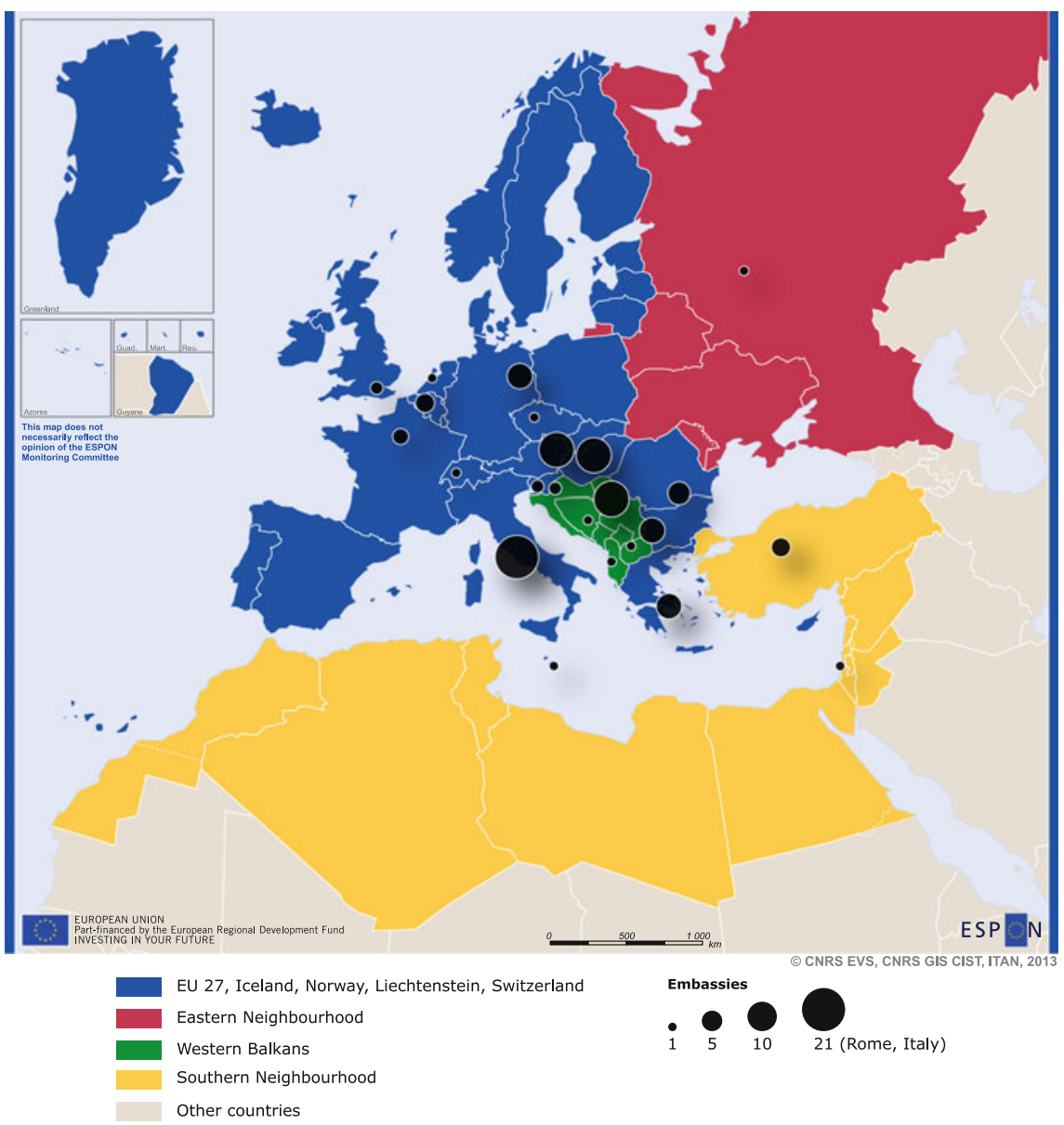

Map 5.8 Idem, by country

Lastly, Kosovo and the Fyrom remain excluded from both strategies due to their geographical position: as continental enclaves, they have neither seashore nor tributary to the Danube. This might foster fragmentation and a two speed integration process in an already fragmented neighbourhood (Fig. 5.1).

\subsubsection{From "Western Balkans" to "South-East Europe"?}

After the 1990 decade of wars, political and economic unrest, this neighbourhood converges in many ways with the general trends observed in Europe: (i) the demographic transitions completion and even the acceleration of natural decline show a convergence with natural demographical trends observed in many parts in 


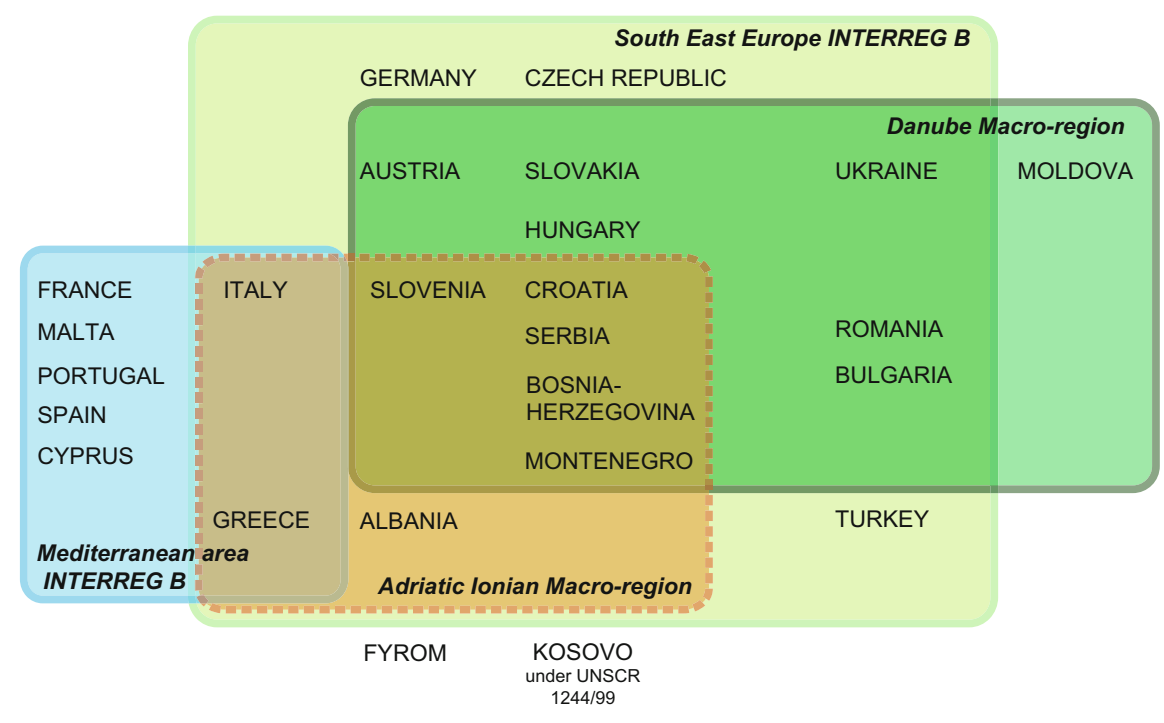

Fig. 5.1 EU transnational cooperation programmes with Western Balkans, 2013

Europe; outmigration is towards western Europe-with an important shift from a "migration" to a "mobility" pattern. (ii) These countries have undertaken deep administrative and territorial reforms after the failure of the socialist regime. The shift from state de-concentrated units to decentralised self-government is on-going, despite unclear distribution of competencies in the legislation, and despite the weakness of civil societies, corruption and political parties' configuration which are holding back further progress. (iii) Regarding economic flows, the vast majority of flows (trade, investment, public aid) are made with or come from the EU. (iv) Regarding diplomatic relations, the capital cities of UE countries host $95 \%$ of the non-resident embassies also competent for the Western Balkans-a key difference with the case of the Black Sea area. (v) Regarding environmental issues, the Western Balkans' regulations converge with those of the EU and are beginning to enter international cooperation.

The major obstacle for further integration to the EU's territory relates to the Western Balkans' internal fragmentation. (i) Whereas borders are vanishing within the European Union, these countries are in the process of borders creation, both internal (federal national delimitations have become international borders) and external, with a very recently strengthened external border control with EU countries. (ii) Transport networks display strong discontinuities within Western Balkans and with European networks. As a result, international openness remains surprisingly low for territories which are so close to the EU's territory. (iii) Market integration between Balkans economies remains insufficient. (iv) There is a rising discrepancy between the northern part of this area and the southern; exchanges between Croatia and the other countries are rejuvenating the historical interplay 


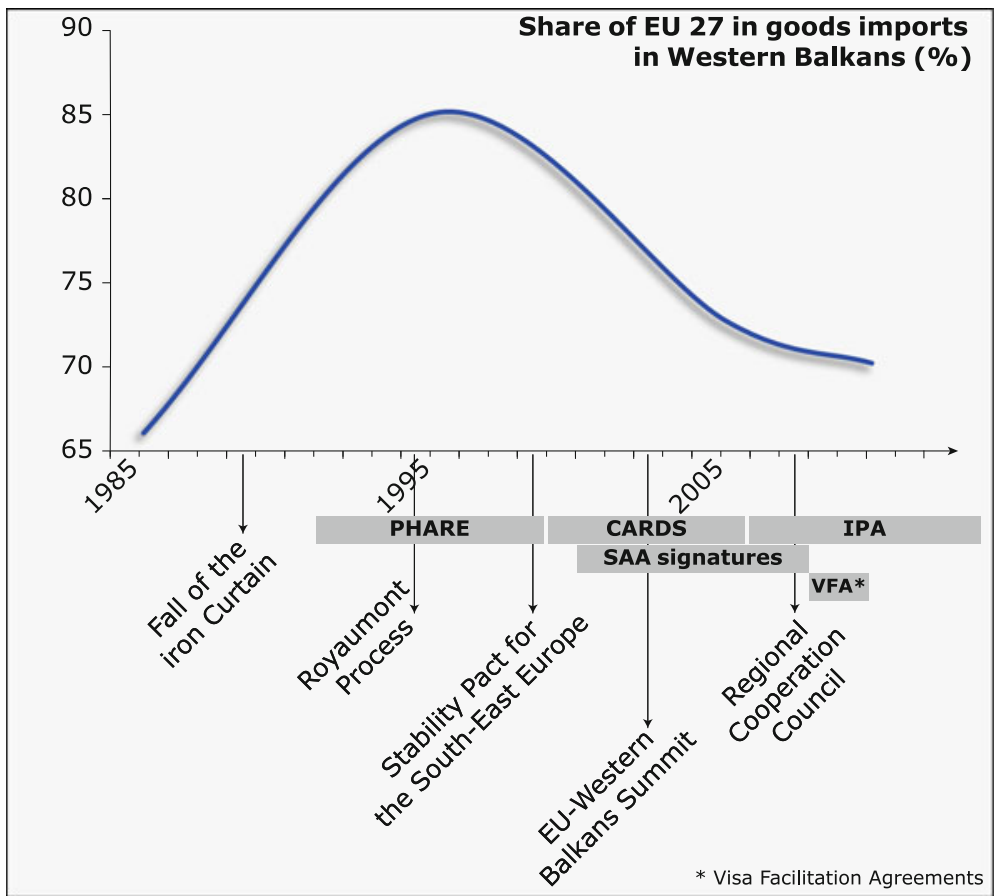

Fig. 5.2 Agreements $v$. real integration with the EU-Western Balkans

between the former Yugoslavian republics, but there is a long way to go to make it an integrated area.

Another obstacle is related to the imbalanced relationship between the EU and the Western Balkans. In the field of energy, many projects have aborted or have been delayed due to numerous bilateral agreements instead of a clear European energy policy. In the field of economic structure and exchanges, we can speak of a core-periphery pattern. The analysis of ODA and FDI flows has shown the rising Russian and Turkish influence. Figure 5.2 shows the ironical decreasing trend of trade integration between the EU and the Western Balkans, whereas agreements multiplied in the two last decades.

This indicates avenues for the EU's action in territorial issues, for instance the development of a thorough network including access roads in order to develop hierarchical networks at local and regional levels instead of only focusing on high speed roads. The EU could further promote the CEFTA as a lever for internal market cooperation instead of a simple antechamber of the accession process, so as to push the Western Balkans economic integration forward. Enhancing territorial cooperation could be better based on cross-border cooperation. Borders can be considered as laboratories: terrestrial borders are rather depopulated areas and are, in a sense, double periphery. Hence, focusing on borders is a good manner to observe the challenges of integration. Turning the core-periphery pattern into a 
cooperation pattern would imply a better sharing of the value chain. Challenges of migration and security border control could be more differentiated between nationals of Western Balkans countries/and other migrants. Turning the high level of working age population as a resource for labour markets in enhancing training, skills, professional and student mobility would promote the mutual advantage of an eased mobility, returning to a time when Yugoslavian citizens could freely travel in Western Europe. Last, but not least, a European common vision should provide a real perspective, shared by all the EU members, highlighting the place of the Western Balkans in the European territory's future.

Open Access This chapter is distributed under the terms of the Creative Commons AttributionNoncommercial 2.5 License (http://creativecommons.org/licenses/by-nc/2.5/) which permits any noncommercial use, distribution, and reproduction in any medium, provided the original author(s) and source are credited. The images or other third party material in this chapter are included in the work's Creative Commons license, unless indicated otherwise in the credit line; if such material is not included in the work's Creative Commons license and the respective action is not permitted by statutory regulation, users will need to obtain permission from the license holder to duplicate, adapt or reproduce the material. 